\title{
Dexras1, a Small GTPase, Is Required for Glutamate-NMDA Neurotoxicity
}

\author{
Yong Chen, ${ }^{1}$ Reas S. Khan, ${ }^{3}$ Alyssa Cwanger, ${ }^{3}$ Ying Song, ${ }^{3}$ Catherine Steenstra, ${ }^{1}$ Sookhee Bang, ${ }^{1}$ Jaime H. Cheah, ${ }^{4}$ \\ Joshua Dunaief, ${ }^{3}$ Kenneth S. Shindler, ${ }^{3}$ Solomon H. Snyder, ${ }^{4,5,6}$ and Sangwon F. Kim ${ }^{1,2}$ \\ Departments of ${ }^{1}$ Psychiatry and ${ }^{2}$ Pharmacology, Center for Neurobiology and Behavior, and ${ }^{3} \mathrm{~F}$. M. Kirby Center for Molecular Ophthalmology, Scheie Eye \\ Institute, Department of Ophthalmology, Perelman School of Medicine, University of Pennsylvania, Philadelphia, Pennsylvania 19104, ${ }^{4}$ Solomon H. Snyder \\ Department of Neuroscience, and the Departments of ${ }^{5}$ Pharmacology and ${ }^{6}$ Psychiatry, Johns Hopkins University School of Medicine, Baltimore, Maryland \\ 21205
}

Dexras1, a small G-protein localized predominantly to the brain, is transcriptionally upregulated by the synthetic glucocorticoid dexamethasone. It has close homology to the Ras subfamily but differs in that Dexras 1 contains an extended $7 \mathrm{kDa}$ C-terminal tail. Previous studies in our laboratory showed that NMDA receptor activation, via NO and Dexras1, physiologically stimulates DMT1, the major iron importer. A membrane-permeable iron chelator substantially reduces NMDA excitotoxicity, suggesting that Dexras1-mediated iron influx plays a crucial role in NMDA/NO-mediated cell death. We here report that iron influx is elicited by nitric oxide but not by other proapoptotic stimuli, such as $\mathrm{H}_{2} \mathrm{O}_{2}$ or staurosporine. Deletion of Dexras1 in mice attenuates NO-mediated cell death in dissociated primary cortical neurons and retinal ganglion cells in vivo. Thus, Dexras1 appears to mediate NMDA-elicited neurotoxicity via NO and iron influx.

\section{Introduction}

The neurotransmitter glutamate acting via NMDA receptors elicits a variety of cellular alterations that are mediated by nitric oxide (NO). NO, in turn, can signal by activating guanylyl cyclase. Additionally, S-nitrosylation of cysteines in diverse proteins is increasingly appreciated as a major vehicle for $\mathrm{NO}$ actions (Kim et al., 2005; Hara and Snyder, 2007; Foster et al., 2009). One mode whereby NO is conveyed to its targets involves the binding of neuronal NO synthase (nNOS) to CAPON, a $55 \mathrm{kDa}$ scaffold protein with a C-terminal domain that binds to the PDZ domain of nNOS (Jaffrey et al., 1998). CAPON then binds to Dexras1, a small GTPase that is a member of the Ras family and was discovered on the basis of selective induction by dexamethasone (Kemppainen and Behrend, 1998; Fang et al., 2000).

Dexras 1 displays $\sim 35 \%$ homology with the Ras family of proteins but differs in incorporating a $7 \mathrm{kDa} \mathrm{C}$-terminal extension,

Received March 27, 2012; revised Nov. 28, 2012; accepted Dec. 24, 2012.

Author contributions: Y.C., J.L.D., K.S.S., S.H.S., and S.F.K. designed research; Y.C., R.S.K., A.C., Y.S., K.S., J.H.C., J.L.D., K.S.S., and S.F.K. performed research; S.H.S. and S.F.K. contributed unpublished reagents/analytic tools; Y.C., R.S.K., S.B., J.L.D., K.S.S., S.H.S., and S.F.K. analyzed data; Y.C., S.H.S., and S.F.K. wrote the paper.

This work was supported by United States Public Health Service Grant DA-00266 and Research Scientist Award DA-00074 to S.H.S. and National Institutes of Health Grants HD026979 and MH079614 to S.F.K. and Grant EY015245 to J.L.D.

The authors declare no competing financial interests.

Correspondence should be addressed to either of the following: Dr. Sangwon F. Kim, Departments of Psychiatry and Pharmacology, Center for Neurobiology and Behavior, Perelman School of Medicine University of Pennsylvania, 125S31st Street, TRL Rm 2207, Philadelphia, PA 19104, E-mail: sangwonk@mail.med.upenn.edu; or Dr. Solomon H. Snyder, Solomon H. Snyder Department of Neuroscience, Pharmacology, and Psychiatry, Johns Hopkins University School of Medicine, 725 N Wolfe Street, WBSB Rm803, Baltimore, MD 21205, E-mail: ssnyder@jhmi.edu.

J. H. Cheah's present address is Eli and Edythe L. Broad Institute of Harvard and Massachusetts Institute of Technology, Chemical Biology Program, 7 Cambridge Center, Cambridge, MA 02142.

DOI:10.1523/JNEUROSCI.1497-12.2013

Copyright $\odot 2013$ the authors $\quad 0270-6474 / 13 / 333582-06 \$ 15.00 / 0$ which it shares with Rhes (Ras Homolog Enriched in Striatum), a G-protein highly enriched in the corpus striatum and involved in the neurotoxicity associated with Huntington's disease (Blumer et al., 2005; Subramaniam et al., 2009). Dexras1 plays a role in synchronizing circadian rhythms, as its deletion impairs circadian entrainment to light cycles and alters phase shifts to light (Cheng et al., 2004). A variety of influences upon adenylyl cyclase and G-protein-linked neurotransmitter influences have been reported for Dexras1. Also, Dexras1 can interact with FE65, an adaptor protein that occurs in a complex with the intracellular domain of the amyloid precursor protein (Cismowski et al., 2000; Nguyen and Watts, 2005; Lau et al., 2008).

NMDA receptor-mediated neurotransmission, via stimulation of nNOS, enhances Dexras1 activity. Thus, NMDA transmission leads to the binding of nNOS to CAPON, which in turn binds to Dexras 1 with the ternary complex of proteins facilitating the S-nitrosylation of Dexras1 to activate its GTP binding activity (Fang et al., 2000).

Recently, we discovered a signaling cascade wherein Dexras1 binds to the peripheral benzodiazepine receptor-associated protein (PAP7), which in turn binds to the divalent metal transporter (DMT1), an iron import channel (Cheah et al., 2006). Stimulation of NMDA receptors activates $\mathrm{nNOS}$, leading to nitrosylation and activation of Dexras1, which, through linkage to PAP7 and DMT1, physiologically enhances iron uptake. As iron is a potentially toxic substance, we wondered whether, following cell stress, Dexras1 might mediate neurotoxicity via an excitotoxic pathway elicited by NMDA neurotransmission and iron entry. In the present study, we have developed mice with targeted deletion of the gene for Dexras1. We demonstrate that deletion of Dexras1 markedly impairs iron uptake elicited by neurotoxic concentra- 


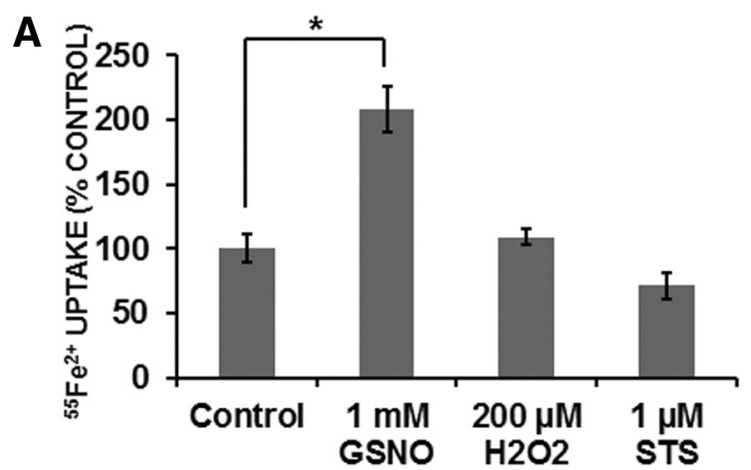

B

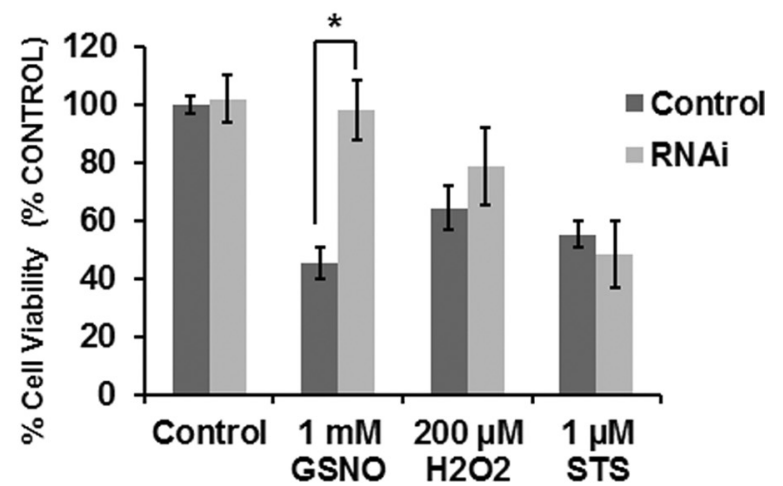

C

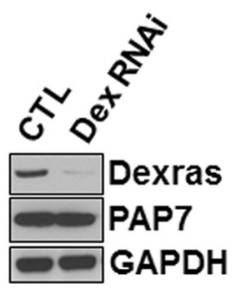

Figure 1. Dexras selectively mediates N0-associated toxicity. $A, P C 12$ cells were treated with the indicated reagents for $2 \mathrm{~h}$, and nontransferrin iron uptake was measured. ${ }^{*} p<0.05$. $\boldsymbol{B}$, PC12 cells were transfected with either scrambled control RNAi or Dexras1 RNAi plasmids and treated with indicated reagent for $24 \mathrm{~h}$. Cell viability was measured by MTT assay. ${ }^{*} p<0.05$. C, Western blotting was performed with Dexras antibody after Dexras RNAi transfection. Experiments were repeated three times, each sample in triplicate.

tions of NMDA and virtually abolishes NMDA neurotoxicity in cortical cultures. In intact mice, NMDA destruction of retinal ganglion cells is abolished in Dexras1 knock-out (KO) mice.

\section{Materials and Methods}

Cells and reagents. HEK $293 \mathrm{~T}$ cells were maintained in DMEM with $10 \%$ FBS, $2 \mathrm{~mm} \mathrm{~L}$-glutamine and $100 \mathrm{U} / \mathrm{ml}$ penicillin-streptomycin at $37^{\circ} \mathrm{C}$ with $5 \% \mathrm{CO}_{2}$ atmosphere in a humidified incubator. PC12 cells were maintained in DMEM with 10\% FBS, 5\% horse serum, $2 \mathrm{~mm}$ L-glutamine, and $100 \mathrm{U} / \mathrm{ml}$ penicillin-streptomycin in the same environment. All chemicals were purchased from Sigma, unless otherwise indicated.

Generation and maintenance of Dexras1/RASD1 KO mice. The geneencoding mouse Dexras1, Rasd1, is located on chromosome 17 and consists of two exons. Rasd $1^{+/-}$mice were generated at Ozgene. The targeting construct was based on the sequence of the C57BL/6 strain Rasd1 gene (GenBank accession number AF239157). The PGK-neo selection cassette was inserted downstream of exon 2. The PGK-neo cassette was flanked by flippase recognition target sites and can be deleted with enhanced flippase recombinase. All the exons were flanked by loxP sites and can be deleted with Cre recombinase. All mice were maintained on a C57BL/6 background. Mice were housed in a $12 \mathrm{~h}$ light/dark cycle at an ambient temperature of $22^{\circ} \mathrm{C}$ and fed standard rodent chow. Animal
A

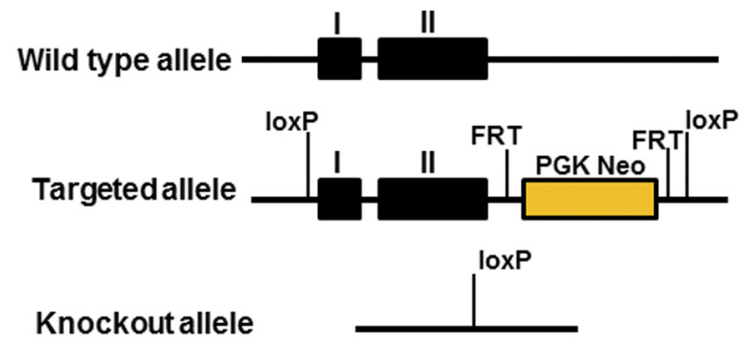

B

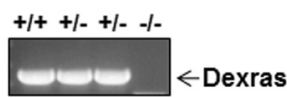

C

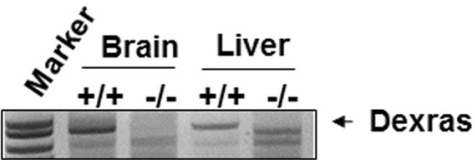

D

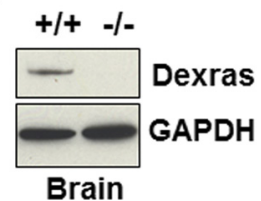

Figure 2. Generation and characterization of Dexras1 KO mice. $\boldsymbol{A}$, Schematic representation of the mouse Dexras1 gene (rasd1) with coding regions shaded black and the exon number indicated on top. The KO allele loses the whole coding regions. $\boldsymbol{B}$, Genotyping. C, RT-PCR analysis from brain and liver tissues. $\boldsymbol{D}$, Western blotting from the brain tissue was performed.

protocols, approved by the Institutional Animal Care and Use Committee of University of Pennsylvania, were used in accordance with the National Institutes of Health Guidelines for the Care and Use of Laboratory Animals.

Genotyping and RT-PCR analysis. Mice were genotyped by PCR analysis of genomic DNA from tail biopsies. Primer sets P1 (CGATCCGCGGCGAAGTCTAC) and P2 (GCGGTGCAAGTCGGGGCTCATCT) yielded a 579 bp product from the wild-type $\left(\mathrm{RASD}^{+}{ }^{+}\right.$) allele. RT-PCR analysis was used to assess whether the RASD1 transcript was missing in the KO mice. RNA was prepared from brain tissues obtained from RASD1 KO mice and their wild-type littermates by using TRIZOL reagent (Invitrogen). cDNA was prepared by using Oligo(dT) primers (Invitrogen) and the Omniscript reverse transcriptase kit (QIAGEN). PCR was performed by using cDNA templates and primers $\mathrm{P} 1$ and $\mathrm{P} 2$ as above.

Quantification of $m R N A$ and iron in retina. $\mathrm{qPCR}$ was performed as we have published previously (Hadziahmetovic et al., 2011), as was retinal iron quantification using bathophenanthroline sulfate.

Iron uptake assay. Primary cortical neurons were dissected out of E16E18 wild-type or Dexras KO mice and plated in 6-well plates at $3 \times 10^{6}$ cells per well. Cells were maintained in Primary Neuron Media (Neurobasal media supplemented with B27 serum, 2 mM L-glutamine, and 100 $\mathrm{U} / \mathrm{ml}$ penicillin-streptomycin) at $37^{\circ} \mathrm{C}$ with $5 \% \mathrm{CO}_{2}$ atmosphere in a humidified incubator. Neurons were aged 14-20 d after plating before being used for iron uptake assays. Cells were treated with various concentration of NMDA for $10 \mathrm{~min}$. Cells were then washed once with warm PBS. Iron uptake was measured as described previously (Cheah et al., 2006).

Measurement of cell death. A $5 \mathrm{mg} / \mathrm{ml}$ stock of MTT (thiazolyl blue tetrazolium bromide; Sigma) was diluted to a final concentration of 0.25 $\mathrm{mg} / \mathrm{ml}$ in HBSS buffer and added to cells after various treatments. Cells were incubated at $37^{\circ} \mathrm{C}$ for $2-4 \mathrm{~h}$; then the MTT reagent was removed and the cells were washed one time in HBSS. The samples were read in a spectrophotometer at OD $580 \mathrm{~nm}$ and OD $630 \mathrm{~nm}$. The OD $580 \mathrm{~nm} / \mathrm{OD}$ 
$630 \mathrm{~nm}$ reading was normalized to control and expressed as a percentage of cell viability.

Propidium iodide (PI) staining. The media was removed and the cells were rinsed once with PBS. PI was diluted into full media at a final concentration of $1 \mu \mathrm{g} / \mathrm{ml}$ and then incubated with cells at $37^{\circ} \mathrm{C}$ for $10 \mathrm{~min}$. Cells were washed once with PBS and then fixed with $4 \%$ paraformaldehyde in PBS for $30 \mathrm{~min}$. To identify cells, the nuclei were stained with Hoechst stain at 1:15,000 for $5 \mathrm{~min}$. PI selectively stains dying cells nuclei (red), whereas Hoechst stains all cells (blue).

Retinal ganglion cell ( $R G C)$ labeling. Retrograde labeling of RGCs was performed as described previously (Shindler et al., 2006). Briefly, Dexras KO male mice and wild-type male mice were anesthetized by intraperitoneal injection with $2 \mathrm{mg}$ of ketamine (Sigma) and $0.2 \mathrm{mg}$ of xylazine (Sigma). Holes were drilled through the skull above each superior colliculus through a midsagittal skin incision; $2.5 \mu$ l of $1.25 \%$ hydroxystilbamidine (Fluorogold; Invitrogen) in sterile water was injected stereotactically into each superior colliculus 1 week before NMDA injection.

Intravitreal injections. The method for intravitreal injections was adapted from previous studies (Liang et al., 2001). Dexras KO and wild-type mice were anesthetized with ketamine/xylazine, and eyes were visualized under a dissecting microscope. The conjunctiva was lifted with forceps and cut from the sclera with Vannas scissors along the corneal limbus. Sclera was penetrated with a 30 -gauge needle passed into the vitreous just posterior to the lens. NMDA (0.8 $\mu \mathrm{l}, 1.2 \mu \mathrm{M}$; Sigma) in PBS was then injected into the vitreous using a $10 \mu \mathrm{l}$ Hamilton syringe with a 32-gauge blunt tip needle. PBS alone was injected in the contralateral eye of each mouse. After injection, antibioitic ointment (Polysporin; Pfizer,) was applied to each eye. The final NMDA concentration in the eye is estimated to be $200 \mathrm{~nm}$, one sixth the concentration of the solution injected based on the volume injected and the average size of the vitreal space.

Quantification of RGC numbers. RGC numbers were counted as described previously (Shindler et al., 2006). Briefly, after death, each eye was removed and fixed in $4 \%$ paraformaldehyde. Dissected retinas were flat mounted on glass slides, viewed by fluorescence microscopy (Eclipse 80i; Nikon), and photographed at $20 \times$ magnification in 12 standard fields: $1 / 6,3 / 6$, and $5 / 6$ of the retinal radius from the center of the retina in each quadrant. RGC numbers shown in each experiment represent the total number of RGCs counted in 12 fields per eye. RGCs were counted by a blinded investigator using image analysis software (Image-Pro Plus 5.0; Media Cybernetics). Statistical comparisons of RGC numbers were performed by ANOVA.

\section{Results}

PC12 cells display many neuronal properties and possess endogenous Dexras1 as well as PAP7 and DMT1 (Cheah et al., 2006). Accordingly, we selected these cells for studies of a possible role of Dexras1 in mediating the effects of neurotoxic levels of NO upon iron uptake and cell viability (Fig. 1). We exposed cells to the NO donor GSNO $(1 \mathrm{~mm}), \mathrm{H}_{2} \mathrm{O}_{2}(200 \mu \mathrm{M})$ or staurosporine $(1 \mu \mathrm{M})$. The concentrations at which we administered these agents are cytotoxic with $50 \%$ cell death $24 \mathrm{~h}$ after treatment (data not
B

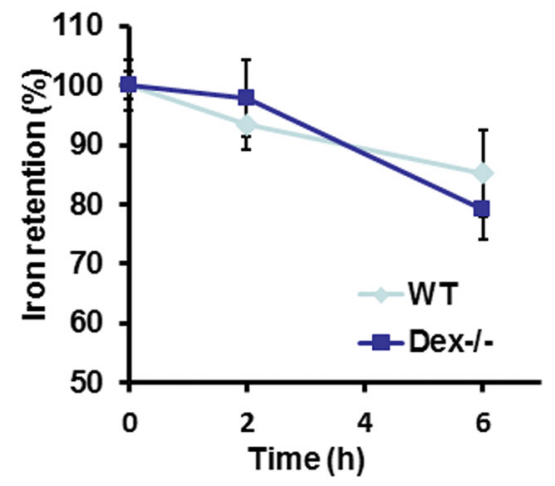

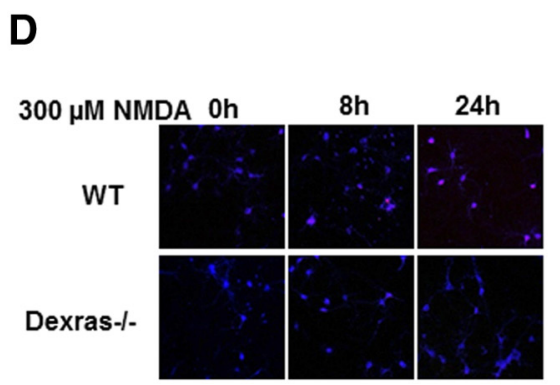

E

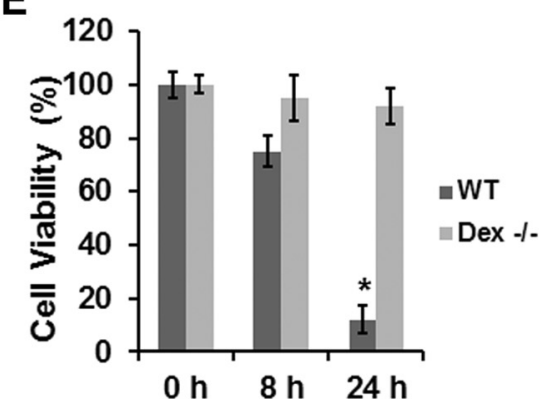

Figure 3. Iron uptake and neurotoxicity mediated by glutamate-NMDA neurotransmission are abolished in Dexras KO mice. $\boldsymbol{A}$, NMDA stimulation increases NTBI uptake (15 min) in primary cortical neurons in a concentration-dependent manner. No increase is seen in washed with PBS and incubated normal growth media for different time periods, and then the amount of iron retained in the cells was meartical neurons from eitherWT or Dexras ${ }^{-1-}$ mice were treated with $300 \mu \mathrm{m}$ NMDA for 10 min and harvested at the different time points. Western blotting was performed. D, Primary cortical neurons were treated with $300 \mu \mathrm{m}$ NMDA for 10 min, and neuronal cell death was examined at the indicated time points using PI staining (red) with DAPI (nucleus). A representative image is shown. $\boldsymbol{E}$, Quantification of three independent experiments of neurotoxicity assays. ${ }^{*} p<0.005$.

shown). At $2 \mathrm{~h}$, when cell viability is normal, GSNO treatment doubles iron uptake, whereas $\mathrm{H}_{2} \mathrm{O}_{2}$ and staurosporine did not change uptake (Fig. 1A). To assess a role for Dexras 1 in the neurotoxic actions of these substances, we developed an shRNA construct that provides almost complete elimination of Dexras1 protein in PC12 cells (Fig. 1 B, C). Depletion of Dexras1 abolishes the cytotoxic actions of GSNO. Strikingly, loss of Dexras 1 does not impair the cytotoxic actions of staurosporine or $\mathrm{H}_{2} \mathrm{O}_{2}$.

To evaluate the impact of Dexras 1 on neurotoxicity in intact rodents, we developed mice with targeted deletion of Dexras1 (Fig. 2). We used a targeting vector to delete the complete open reading frame of Dexras1 (Fig. 2A). PCR genotyping and RTPCR confirm the complete genomic deletion of Dexras and the absence of Dexras mRNA in brain and liver (Fig. $2 B, C$ ). The mutant mice appear grossly normal. There was no difference from wild-type in body size, weight, or locomotor activity at the age of 8 weeks. Mice lived up to 16-18 months, and gross ana- 
$\mathbf{A}$

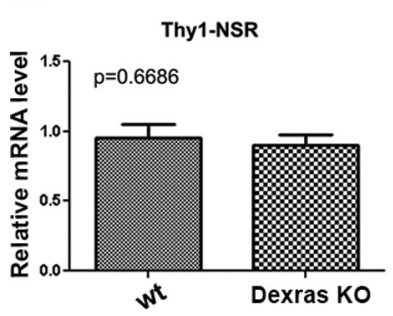

DMT1-1 NSR
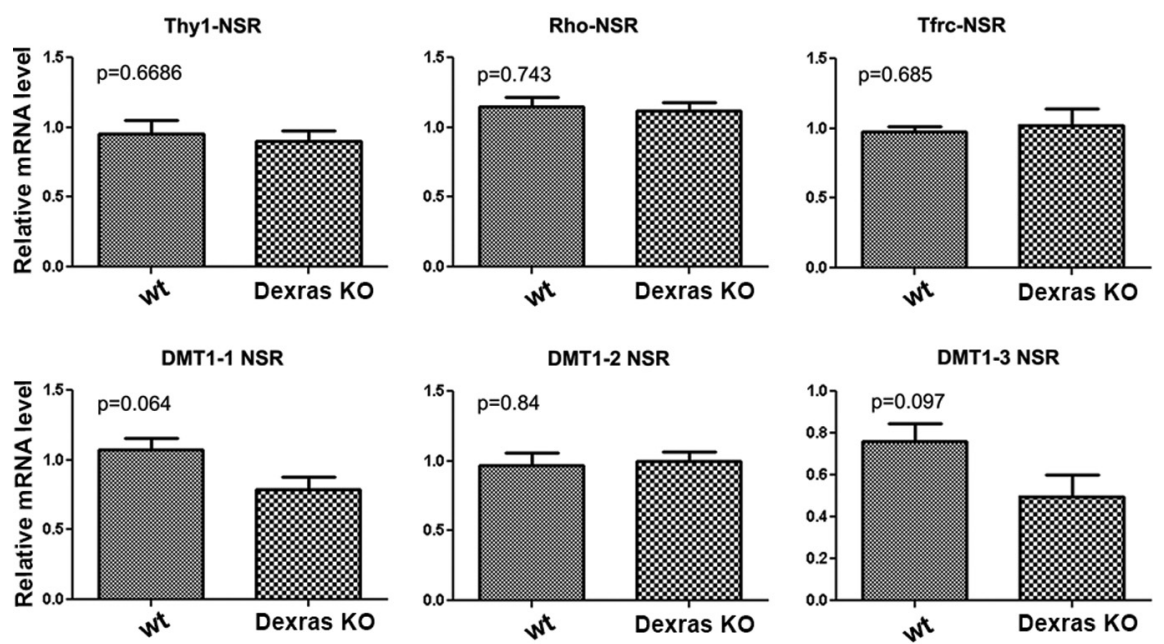

B
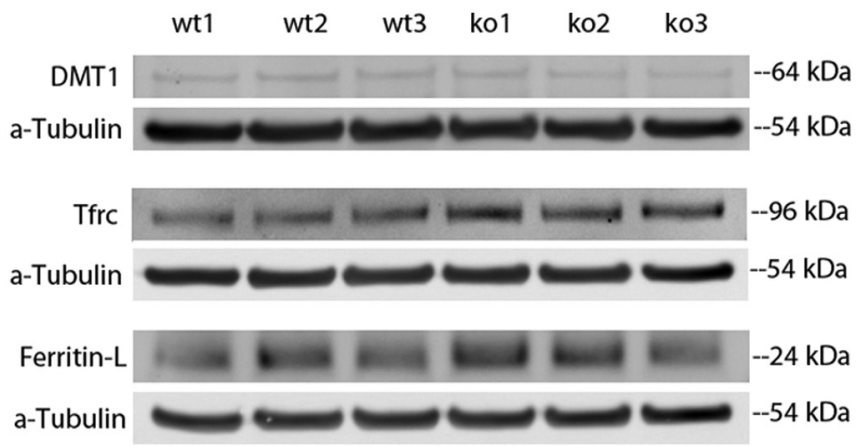

C

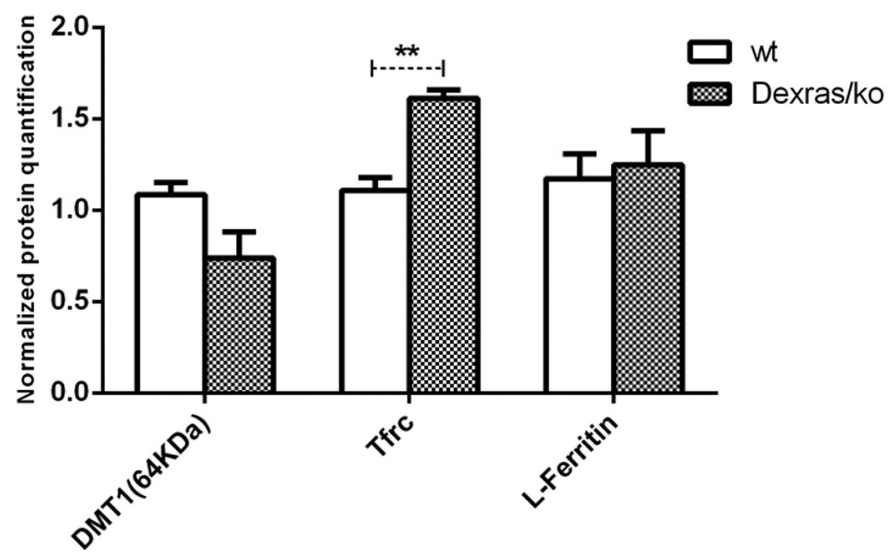

D

Iron Content of Retina samples on Dexras/ko \& wt mice

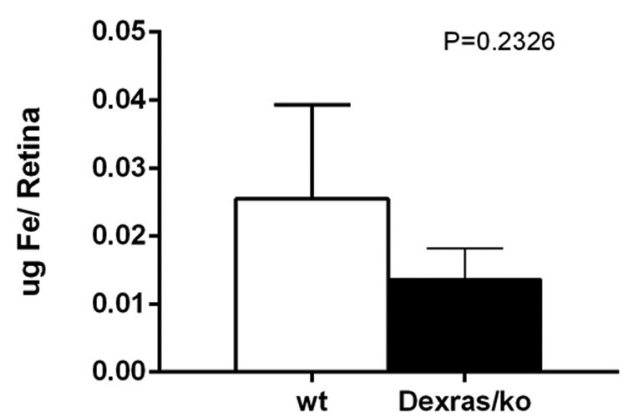

Figure 4. Effect of Dexras $K 0$ on mRNAs and proteins involved in iron homeostasis or iron levels in the retina. $A, R T-P C R$ of various genes involved in iron homeostasis and retina cell markers. $B$, C, Western analysis was performed to detect DMT1, Tfrc (transferrin receptor), and ferritin-L. ${ }^{* *} p<0.01 . D$, Retinal nonheme iron content. tomic dissection of 16-month-old mice reveals no apparent abnormalities in organs of the adult mutant mice. The absence of major aberrations in the mice corresponds to results from another group that also developed Dexras1 KOs (Cheng et al., 2004).

To determine whether Dexras1 influences iron uptake associated with neurotoxicity, we exposed cortical cultures to various concentrations of NMDA, including cytotoxic levels $(100-300 \mu \mathrm{M})$ for 10 min and measured iron uptake. At the cytotoxic concentrations of NMDA, we observe substantial increases in iron uptake with $300 \mu \mathrm{M}$ NMDA eliciting a doubling of iron uptake (Fig. 3A). No increase of iron uptake is apparent in Dexras1deleted brain cultures. On the other hand, iron efflux was not affected in primary neurons from Dexras ${ }^{-1-}$ mice (Fig $3 B$ ). Moreover, we found that the expression levels of proteins involved in iron homeostasis, such as amyloid precursor protein, TfR, DMT1, and ferritin, are similar in neuronal cultures between WT and Dexras $^{-1-}$ mice (Fig. 3C). Thus, these findings establish a role for Dexras1 in mediating iron uptake in NMDA-mediated neurotoxic insults. These findings confirm and extend our previous observations in PC12 cells that the stimulation of iron uptake by GSNO $(100 \mu \mathrm{M})$ is prevented by depletion of Dexras1 using RNA interference (Cheah et al., 2006).

We also examined cytotoxic actions of NMDA in the same cortical cultures (Fig. $3 D, E)$. We used the well-characterized regimen of NMDA treatment that elicits delayed neurotoxicity, thought to mimic events in vascular strokes (Koh and Choi, 1988; Dawson et al., 1991). Cortical cultures were exposed to $300 \mu \mathrm{M}$ NMDA for $10 \mathrm{~min}$ and then examined after 8 and $24 \mathrm{~h}$. As has been reported by numerous investigators, no loss of cell viability is evident at $8 \mathrm{~h}$, whereas at $24 \mathrm{~h}$ viability is decreased by $>90 \%$. Dexras1 deletion provides dramatic protection against this toxicity, with no evident loss of viability.

To extend these findings to intact animals, we evaluated retinal toxicity elicited by NMDA injection into the eyes of mice, a procedure known to selectively destroy retinal ganglion cells (Sucher et al., 1997). First, we examined various genes involved in iron trafficking as well as markers for retinal cells. The qPCR cycle threshhold for Dexras1 in wild-type neural retinas was 29 (mid-range, of40 cycles) but was undetectable in Dexras1 KOs. There were no significant differences for wild-type versus KO for transferrin receptor, rhodop- 
sin (rod photoreceptor-specific), Thyl (ganglion cell-specific), or any of the DMT1 isoforms. These results are further confirmed by Western blotting examining the levels of protein expression for ferritin and DMT1 (Fig. 4B,C). Interestingly, the protein level of $\mathrm{TfR}$ is slightly higher in Dexras $^{-1-}$, and it may be a reflection of slightly lower levels of iron. We measured retinal iron levels directly, but the levels were variable and there was no statistically significant (Fig. 4D) difference between the genotypes. Thus, Dexras1 KO does not notably affect baseline iron levels or ganglion cell or rod photoreceptor numbers in the normal retina.

Five days after NMDA administration, we observed a $60 \%$ reduction in numbers of retinal ganglion cells (Fig. $5 A, B$ ). The Dexras1-deleted mice are completely protected from this neurotoxicity. Detailed histologic examination reveals no difference in the morphology of retinal ganglion cells or any other cell type of the retina between wild-type mice and Dexras1-deleted mice in the absence of NMDA administration (data not shown).

\section{Discussion}

In the present study, we have established a major role for Dexras1 in mediating both iron uptake and cell viability under NMDA-excitotoxic conditions. The linkage between cell viability and iron uptake is selective for NO, as cytotoxic concentrations of GSNO increase iron uptake, whereas comparably toxic levels of $\mathrm{H}_{2} \mathrm{O}_{2}$ and staurosporine fail to do so. Moreover, the neurotoxic actions of GSNO, but not those of other agents, are prevented by Dexras1 depletion. Experiments using Dexras1 KO mice provide compelling evidence for its importance in iron uptake and neurotoxicity. In cortical cultures of Dexras1 KOs, stimulation by NMDA both of iron uptake and of neurotoxicity is abolished. In intact mice, the marked loss of retinal ganglion cells elicited by NMDA is completely prevented in the Dexras1 KOs. Our findings suggest that Dexras 1 mediates NMDA neurotoxicity via its enhancement of iron uptake, as Dexras1 deletion prevents both processes. Moreover, previously we observed that NMDA neurotoxicity in cortical cultures is prevented by iron chelator treatment (Cheah et al., 2006).

The use of Dexras1 mutant mice substantially strengthens evidence for a signaling cascade wherein glutamate, acting via NMDA receptors, activates nNOS to form NO, which nitrosylates and activates Dexras1, which, through a link to PAP7, increases iron uptake via DMT1. As reported previously (Cheah et al., 2006), Dexras1 stimulation of iron uptake stems from its GTPase activity, as constitutively active Dexras1 is associated with enhanced stimulation of iron uptake.

Rhes (Dexras2) is the only Ras homolog that closely resembles Dexras1, with $\sim 62 \%$ amino acid homology (Falk et al., 1999). Whereas Dexras1 is induced by glucocorticoids, Rhes is selectively stimulated by thyroid hormone (Vargiu et al., 2001). Most strikingly, Rhes is uniquely concentrated in the corpus striatum, where its binding to mutant huntingtin is thought to underlie the selective damage to the corpus striatum in
Huntington's disease (Subramaniam et al., 2009). Like Dexras1, Rhes does bind to PAP7 (Cheah et al., 2006) and so might regulate striatal iron deposition, which might participate in Huntington's disease pathophysiology. Consistent with this possibility, iron levels in the striatum are increased in Huntington's disease patients (Dexter et al., 1991).

In our earlier study, we addressed physiologic regulation of iron transport by Dexras1 in response to NMDA-NO activation. Our present study focuses on the pathogenic actions of iron. Iron is well known to be toxic in excess; and in the brain, iron accumulation has been linked to numerous neurodegenerative diseases (McCord, 1998; Thomas and Jankovic, 2004). In particular, Salazar et al. (2008) showed that DMT1, which is modulated by Dexras1, plays a critical role in iron-mediated neurodegeneration of Parkinson's disease (see also Snyder and Connor, 2009).

The dramatic protection from NMDA neurotoxicity elicited by deletion of Dexras1 may have therapeutic implications. Glutamate excitotoxicity has been implicated in the retinal ganglion cell loss of numerous optic neuropathies, including glaucoma (Dreyer, 1998; McCord, 1998) and dominant optic atrophy (Nguyen et al., 2011), as well as neuronal loss in multiple sclerosis models (Pitt et al., 2000), where significant ganglion cell loss occurs secondary to optic neuritis (Shindler et al., 2008; Quinn et al., 2011). Conceivably, drugs that selectively block Dexras1 may be neuroprotective in these optic neuropathies, vascular stroke, and other neurodegenerative diseases. Because Dexras1 differs markedly in structure from other members of the Ras family and other small G-proteins, it may be feasible to develop highly selective and safe inhibitors of Dexras1 function with therapeutic potential. 


\section{References}

Blumer JB, Cismowski MJ, Sato M, Lanier SM (2005) AGS proteins: receptor-independent activators of G-protein signaling. Trends Pharmacol Sci 26:470-476. CrossRef Medline

Cheah JH, Kim SF, Hester LD, Clancy KW, Patterson SE 3rd, Papadopoulos $\mathrm{V}$, Snyder SH (2006) NMDA receptor-nitric oxide transmission mediates neuronal iron homeostasis via the GTPase Dexras1. Neuron 51:431440. CrossRef Medline

Cheng HY, Obrietan K, Cain SW, Lee BY, Agostino PV, Joza NA, Harrington ME, Ralph MR, Penninger JM (2004) Dexras1 potentiates photic and suppresses nonphotic responses of the circadian clock. Neuron 43:715728. CrossRef Medline

Cismowski MJ, Ma C, Ribas C, Xie X, Spruyt M, Lizano JS, Lanier SM, Duzic E (2000) Activation of heterotrimeric G-protein signaling by a rasrelated protein: implications for signal integration. J Biol Chem 275: 23421-23424. CrossRef Medline

Dawson VL, Dawson TM, London ED, Bredt DS, Snyder SH (1991) Nitric oxide mediates glutamate neurotoxicity in primary cortical cultures. Proc Natl Acad Sci U S A 88:6368-6371. CrossRef Medline

Dexter DT, Carayon A, Javoy-Agid F, Agid Y, Wells FR, Daniel SE, Lees AJ, Jenner P, Marsden CD (1991) Alterations in the levels of iron, ferritin and other trace metals in Parkinson's disease and other neurodegenerative diseases affecting the basal ganglia. Brain 114:1953-1975. CrossRef Medline

Dreyer EB (1998) A proposed role for excitotoxicity in glaucoma. J Glaucoma 7:62-67. Medline

Falk JD, Vargiu P, Foye PE, Usui H, Perez J, Danielson PE, Lerner DL, Bernal J, Sutcliffe JG (1999) Rhes: a striatal-specific Ras homolog related to Dexras1. J Neurosci Res 57:782-788. CrossRef Medline

Fang M, Jaffrey SR, Sawa A, Ye K, Luo X, Snyder SH (2000) Dexras1: a G protein specifically coupled to neuronal nitric oxide synthase via CAPON. Neuron 28:183-193. CrossRef Medline

Foster MW, Hess DT, Stamler JS (2009) Protein S-nitrosylation in health and disease: a current perspective. Trends Mol Med 15:391-404. CrossRef Medline

Hadziahmetovic M, Song Y, Wolkow N, Iacovelli J, Grieco S, Lee J, Lyubarsky A, Pratico D, Connelly J, Spino M, Harris ZL, Dunaief JL (2011) The oral iron chelator deferiprone protects against iron overload-induced retinal degeneration. Invest Ophthalmol Vis Sci 52:959-968. CrossRef Medline

Hara MR, Snyder SH (2007) Cell signaling and neuronal death. Annu Rev Pharmacol Toxicol 47:117-141. CrossRef Medline

Jaffrey SR, Snowman AM, Eliasson MJ, Cohen NA, Snyder SH (1998) CAPON: a protein associated with neuronal nitric oxide synthase that regulates its interactions with PSD95. Neuron 20:115-124. CrossRef Medline

Kemppainen RJ, Behrend EN (1998) Dexamethasone rapidly induces a novel ras superfamily member-related gene in AtT-20 cells. J Biol Chem 273:3129-3131. CrossRef Medline

Kim SF, Huri DA, Snyder SH (2005) Inducible nitric oxide synthase binds, S-nitrosylates, and activates cyclooxygenase-2. Science 310:1966-1970. CrossRef Medline
Koh JY, Choi DW (1988) Vulnerability of cultured cortical neurons to damage by excitotoxins: differential susceptibility of neurons containing NADPH-diaphorase. J Neurosci 8:2153-2163. Medline

Lau KF, Chan WM, Perkinton MS, Tudor EL, Chang RC, Chan HY, McLoughlin DM, Miller CC (2008) Dexras1 interacts with FE65 to regulate FE65-amyloid precursor protein-dependent transcription. J Biol Chem 283:34728-34737. CrossRef Medline

Liang FQ, Anand V, Maguire AM, Bennett J (2001) Intraocular delivery of recombinant virus. Methods Mol Med 47:125-139. CrossRef Medline

McCord JM (1998) Iron, free radicals, and oxidative injury. Semin Hematol 35:5-12. Medline

Nguyen CH, Watts VJ (2005) Dexras1 blocks receptor-mediated heterologous sensitization of adenylyl cyclase 1. Biochem Biophys Res Commun 332:913-920. CrossRef Medline

Nguyen D, Alavi MV, Kim KY, Kang T, Scott RT, Noh YH, Lindsey JD, Wissinger B, Ellisman MH, Weinreb RN, Perkins GA, Ju WK (2011) A new vicious cycle involving glutamate excitotoxicity, oxidative stress and mitochondrial dynamics. Cell Death Dis 2:e240. CrossRef Medline

Pitt D, Werner P, Raine CS (2000) Glutamate excitotoxicity in a model of multiple sclerosis. Nat Med 6:67-70. CrossRef Medline

Quinn TA, Dutt M, Shindler KS (2011) Optic neuritis and retinal ganglion cell loss in a chronic murine model of multiple sclerosis. Front Neurol 2:50. CrossRef Medline

Salazar J, Mena N, Hunot S, Prigent A, Alvarez-Fischer D, Arredondo M, Duyckaerts C, Sazdovitch V, Zhao L, Garrick LM, Nuñez MT, Garrick MD, Raisman-Vozari R, Hirsch EC (2008) Divalent metal transporter 1 (DMT1) contributes to neurodegeneration in animal models of Parkinson's disease. Proc Natl Acad Sci U S A 105:18578-18583. CrossRef Medline

Shindler KS, Guan Y, Ventura E, Bennett J, Rostami A (2006) Retinal ganglion cell loss induced by acute optic neuritis in a relapsing model of multiple sclerosis. Mult Scler 12:526-532. CrossRef Medline

Shindler KS, Ventura E, Dutt M, Rostami A (2008) Inflammatory demyelination induces axonal injury and retinal ganglion cell apoptosis in experimental optic neuritis. Exp Eye Res 87:208-213. CrossRef Medline

Snyder AM, Connor JR (2009) Iron, the substantia nigra and related neurological disorders. Biochim Biophys Acta 1790:606-614. CrossRef Medline

Subramaniam S, Sixt KM, Barrow R, Snyder SH (2009) Rhes, a striatal specific protein, mediates mutant-huntingtin cytotoxicity. Science 324:1327-1330. CrossRef Medline

Sucher NJ, Lipton SA, Dreyer EB (1997) Molecular basis of glutamate toxicity in retinal ganglion cells. Vision Res 37:3483-3493. CrossRef Medline

Thomas M, Jankovic J (2004) Neurodegenerative disease and iron storage in the brain. Curr Opin Neurol 17:437-442. CrossRef Medline

Vargiu P, Morte B, Manzano J, Perez J, de Abajo R, Gregor Sutcliffe J, Bernal J (2001) Thyroid hormone regulation of rhes, a novel Ras homolog gene expressed in the striatum. Brain Res Mol Brain Res 94:1-8. CrossRef Medline 